\title{
ADDRESS
}

BY

\section{WALTER HOUGH}

VICE-PRESIDENT AND OHAIRMAN OF SEOTION H FOR 1905

BEFORE THE

\section{SECTION OF ANTHROPOLOGY}

AMERICAN ASSOOIATION FOR THE ADVANCEMENT OF SOIENOE

New Orleans Meeting

DeCEMBER 29, 1905-J JNUARY 4, 1906

\section{Reprinted from the Proceedings of the Ameriodn Association fot} the Advanogment of Scienoe, Vol. LV, 1906 

SECTION H.

ANTHROPOLOGY. 


\section{OFFICERS OF SECTION H.}

\section{Vice-President and Chairman of the Section.}

Hugo MÜnsterberg, Cambridge, Mass.

\section{Secretary.}

Geo. H. Pepper, New York, N. Y.

\section{Member of Council.}

Alcée Fortier.

\section{Sectional Committee.}

WALTER Hough, VICE-President, I905; Hugo MÜNSTERBERG, Vice-President, I906; GEO. H. PEPPER, Secretary, I904-'o8.

W J McGee, I year; Miss Alice C. Fletcher, 2 years; Geo. Grant MACCURDY, 3 years; Alës HRdíICKA, 4 years;

Franz BOAS, 5 years.

\section{Member of General Committee.}

Miss CORNELIA HoRSFORD.

Press Secretary.

Geno. H. Pepper. 
ADDRESS

BY

\section{WALTER HOUGH,}

VICE-PRESIDENT AND CHAIRMAN OF SECTION H FOR 1905.

\section{PUEBLO ENVIRONMENT}

The great city of New Orleans lies near the threshold of a portion of the continent to which the term mysterious is often applied. With good reason the southwest receives the appellation; for its treasures of natural scenery lavished with inconceivable largess, the picturesque aboriginal population who retain in great part the customs of immemorial centuries, and the silent mounds which are what remains of the homes of the ancient people, all speak of the Old New World cradled and fostered in the bosom of the inaccessible mountains, till it became a representation of the man's progress toward civilization.

The southern portion of the Rocky Mountain Highland has two chief geographic features, the one a depression called the Great Interior Basin and the other the Pueblo plateau. The latter may be subdivided into the Rio Grande valley, the Colrado plateau, and the Gila Slope, lying in the four political divisions named Colorado, Utah, Arizona, and New Mexico.

This plateau, which contains the bulk of the elevation on the western half of the United States, is mainly embraced in the triangle lying between the eastern side of the Rocky mountains and the Rio Colorado, the western side bounded by Great Basin. Its slope is from north to south in the eastern portion where the Rio Grande drains the trough lying just east of the continental uplift, but the main slope is toward the southwest and is drained by the Colorado and its 
affluents. The plateau lies from four to ten thousand feet above sea level, but there are great contrasts in elevation from I 4,000 feet above to 300 below the datum. In this region the north and south ranges of the Rockies break up and form a complex of mountains running east and west, plateaus, plains, basins, buttes, broad valleys and narrow canyons giving great diversity of the most remarkable natural features to be found in the world.

The geology is that of later rocks, principally the easily eroded Cretaceous and other mesozoic formations. Tremendous volcanic activity in former times has poured out vast floods of lava which together with tuff form the most noticeable physiographic features of the region.

Latitude, elevation, and natural barriers here conspire to produce modifications in climate. This is seen in the convolutions of the isotherms of $50^{\circ}, 59^{\circ}$ and $68^{\circ}$ crossing the region, the scanty rainfall occurring in the winter and summer months, the excessive insolation, the extremes of day and night temperature, the high winds and rarefied air, which characterize the arid environments.

The fitness of the southwest to sustain biotic forms depends mainly upon rainfall, which itself is regulated by cosmic and geographic conditions. Thus the uprush of heated air from the sun-baked plateaus during the summer draws in moistureladen air from the oceans, producing rains which are unequally distributed; the higher mountains acting as condensing centers receive the most, while the plains are scantily watered. The receptivity of the land must also be considered, the mountains covered with vegetation storing water and the bare land shedding it into the rivers which must carry at times vast floods and during long periods remain perfectly dry. Everywhere is evidence of the colossal agencies which are at work reducing the land to sea-level. This workshop is littered with the bones of the mountains, and the dust that is sorted by water and wind moves freely to lower levels or is blown higher to again resume its gravitational course.

Despite the generally adverse conditions set forth, there flourishes here a flora of a peculiar character which forms 
the basis of subsistence for an extensive fauna, and also the new-comer man who has pinned much of his faith to natures supply. The region is not in any part a desert in the true sense of the term, which is applied to lands deserted because of an inhibition of life; but it is rather a semi-arid environment, in which a preponderance of desiccative and other factors have restricted and minimized life. These restrictions are observed in full force among the plants fixed in the earth, and therefore played upon by all the natural forces to which they must adapt themselves by slower changes than are required by higher biotic forms. The characteristic climatic flora is thus xerophytic, or dry-leaved, where the leaves are small with devices for preventing too rapid evaporation, stems contain clorophyl and act when leaves fall away, etc.; these are adaptations which give some plants the freedom of the desert. Other plants are succulent and spring to quick fruition when rains occur; other plants have perfected water-storing devices in stem, root, and branches, as the cacti, yucca, atriplex, sarcobatus, etc., and still others can live in soils containing an excess of mineral salts.

Most of the desert plants bear witness to the struggle with sun, wind, rarefied air, and inhospitable soil; thus they present a gnarled, wrinkled, and bizarre appearance, often similating trees dwarfed by the gardeners' art. Unlimited opportunity is here for isolation by natural boundaries, which, if not a factor in the origin of species, at least powerfully aids in the preservation of species.

Much that is observed as to plant life is true also of animal life, giving a fascies by which Merriam's Austral regions may be characterized.

In all discussions of this environment, little or no attention has been paid to the effects of light, which is here at its maximum. Without entering into detail as to the physiological sequelæ of light from other parts of the spectrum, the rays from the violet end may be considered. These rays affect all life submitted to them in a harmful manner by checking or prohibiting cell growth or metabolism. It will be found that many of the protective features of xerophytic plants and 
of animals which are attributed to aridity, rarefied air, soil, etc., are adaptations due to avoidance of dangerous rays of light. This is to be noticed in the habit of some delicate plants which thrive in the shade of hardy plants, the protective covering and nocturnal habits of animals, and the architecture and shelter instincts, as well as skin color of the ancient and modern Indians who lived in caves, cliff shelters, or cavate houses, or whose pueblos as a whole or as to the individual houses were constructed to admit a minimum of light.

But from far difierent causes, though still environmental, pueblos were generally oriented with reference to the east; first, for the utilitarian purpose of receiving the early morning sun, grateful after the chilly nights of the high regions; and second, on account of the importance of the rising sun in heliolatry.

It is difficult to realize the immense modification of animal and vegetable life which the white man has wrought in this region during the thirty years of his active occupancy. At the beginning of this period the region was well grassed and supplied with other vegetation adequate to the needs of vast herds of antelope, elk and deer; rodent animals and birds were plentiful, and carnivores had abundance of prey. As a result of vegetation a humus had formed on all protected situations, rainfall was absorbed and equalized in distribution and the terrific denudation which gashes the land at present was not begun.

The country was adapted to grazing and especially favorable on account of temperature and latitude, and at once great herds of cattle, horses and sheep were introduced from Texas where the range had failed. The result was that the range became overstocked, the grass disappeared under the tongues and hoofs of myriads of domestic animals, shrubs and trees were browsed and destroyed or swept away by fires, from certain regions species of plants vanished, and the land lay bare to the augmented winds and torrential rains. Trails became profound arroyos and the humus vanished in the streams and the surface of the country was stone, sand and gravel. Not the least of this baneful influence was the drying up of springs and other sources of water, and more than one observer collected data going to prove the progressive desiccation of the Pueblo region. 
These facts must be borne in mind in discussion of the environment of the southwest. As an example, it may be stated that in the exploration of one ancient pueblo at Winslow, Arizona, the bones of thirty-seven species of animals were taken from the house refuse; it is not probable at present that a naturalist could collect five of these spacies from the environment. Wherever the explorer's spade has been put in the ancient ruins, facts of this character come to his notice, even if he has not heard the story from the early settlers or Indian traditionists.

There is no doubt that cycles of dry and wet seasons occur in the southwest, but the periods have not been definitely observed. Inferential data has been securea from expluration in the ancient ruins that render it possible to explain the migrations of early populations.

The conditions of the environment briefiy recapitulated are:

I. A plateau of considerable elevation isolated geographially

2. Slight rainfall, locally distributed; absence of cloud blanket; excessive light, radiation and evaporation; high winds, dust storms; rarified air.

3. Forested mountains, plains with xerophytic, hyhrophytic, and halophytic vegetation; plant colonies; desert animals.

Within this general enclave we have several sub-envirouments which may be considered from the point of view of the availability for habitation by man.

Sub-Environments:

r. Prohibitive to man and in great degrees to animal and vegetal life.

2. Precarious except to man in low grade of culture, as roving, hunting, and naturistic tribes. Animal and vegetal life sufficient.

3. Habitable by man acquainted with agriculture, but more or less precarious. 
4. Favorable for agriculture and production of economic surplus.

The sub-environments more favoring in the struggle for existence are:

I. Mountains at sources of rivers. Here are narrow valleys for agriculture with occasional irrigation; game, nuts, fruits and plants; timber; building material, etc. The temperature cold with short growing season.

2. High platealis with marshes, lakes, ponds. Land lying well for catchment of water. Temperature as in I.

3. Mesa country, with broad plains and valleys; springs; streams flushed at seasons.

4. Riverain lands in lower stream valleys suitable for irrigation by canals or warping.

The effect of this environment upon plants is to reduce them to their lowest terms; animals, to modify them in importtant ways; man, to subject his mind to the stress of severe conditions, reacting noticeably on his body, and mightily on his thought and material progress.

The environment was suitable; or extinction of tribes followed or a movement was made to a new sub-environment. Thus the constant and seemingly erratic migration of tribes which have covered the Pueblo region with remains of ancient towns may have been due to natural causes which disenvironed them, such as earthquakes, failure of springs, etc. The final localization of the pueblos is an index, in large measure, of the reginal fitness.

It is probable that the tribes coming into the Pueblo environment were at first confined to mountain regions where there is a permanent water supply and natural subsistence, and that gradually they spread along the water courses and into all the sub-environments. With the increase of population the building of permanent villages of stone, the beginning or extension of the agriculture of maize-which cereal is a major factor in the distribution and permanency of tribes--the settlement of the Pueblo region went on apace. 
It is apparent that in the advanced culture stage of the Pueblos the privations of an environment had less restrictive character than in earlier stages. Gradually they attain superiority to the environment which had worked on them to the extent of its capabilities, and this has been the history of the growth of mankind.

Thus the regions least favored, in fact, prohibitive to tribes who had not the schooling of experience, became the seed fields of advanced tribes. Given unfailing springs as a starting point, the waste sand flats of streams occasionally and temporarily filled with water became cornfields which yielded bountiful returns to the Indian agriculturist. These regions yielded the surplus which is necessary for the building of an advanced civilization, and here rather than in the favorable subenvironments arose the true agriculture of cereals on which basis the civilizations of the world now rest.

The environment determined largely the methods of application of water to land. North of the great ridge which crosses the southern portions of Arizona and New Mexico forming the watershed of the Gila salt river are found the more primitive methods of irrigation, that is by simple canals diverting water from streams to the nearest land. and by warping or spreading a fan of water from a point in the stream where the bank and bed of the stream are at a uniform level by slight temporary barriers. South of the ridge which absorbs the cloud moisture and diverts it into the Gila we find a more complicated system in the trunk and lateral canals of great extent employed by the Indians who inhabited this region. Here the rivers lent themselves to irrigation, and agricultural tribes were led to employ the facilities to their betterment.

The somatology and culture of the Pueblos in ancient times are known to have presented a remarkable uniformity, and here may be found an argument for the compelling, panurgic force of the environment. Time and isolation must be considered as concomitant factors in the formation of a Pueblo type under the peculiar transforming character of the environment, which, while it produced uniformity in many respects, may have 
tended to perpetuate the five language stocks which prevail in the region.

The most obvious effects of Pueblo environment are those connected with irrigation, architecture, arts and religion, and in the latter the fullest sway of its causation is shown.

Tithout doubt the following of these and other lines of inquiry relating to the habits and customs of the Pueblo Indians will be productive of valuable material on this subject, necessarilybut sketched in this communication. 
REPORT OF THE SECRETARY OF SEC'TION H.

[No papers were read before Section $\mathrm{H}$ at the New Orleans Meet.ng.] 

